\title{
The effect of mulberry leaves enrichment with different nutritional supplements on biological aspects and economic traits of silkworm, Bombyx mori (L.)
}

\author{
Hamzah, M. Kamel ${ }^{1}$; Abo laban, G.F. ${ }^{1}$ and M. M. Nabil ${ }^{2}$ \\ ${ }^{1}$ Department of Plant Protection, Faculty of Agriculture, AL-Azhar Univ., Nasr City, Cairo, Egypt. \\ ${ }^{2}$ Plant Protection Research Institute, Agricultural Research Center, Giza, Egypt.
}

\begin{abstract}
The presented study was carried out during spring season of 2016 at the laboratory of Department of Plant Protection, Faculty of Agriculture AL-Azhar University. It was planned to evaluate the certain biological and economic parameters of (HoxKKxG2xV2) hybrid of silkworm, Bombyx mori (L.) fed on mulberry leaves Morus alba (Rose variety), supplemented with four types of protein sources (pollen grains, royal jelly,an amino acid and bee honey) during fourth and fifth instars of B.mori larvae, and to study the impact of these supplements on the larval duration, and cocoon, shell and pupal weight and shell ratio. Many studies were accomplished on the effects of mulberry leaves enrichment with protein supplements on certain biological and economic parameters. One of the alternative ways to improve the larval feeding is the enrichment of mulberry leaves with supplementary pollen grains, royal jelly, amino acid and bee honey. Obtained results showed that feeding of larvae on leaves supplemented by pollen grains, royal jelly, amino acid and bee honey increased fresh cocoon weight, cocoon shell weight; shell/ cocoon ratio. Also such feeding led to shorter larval duration and decreased larval mortality percentages.
\end{abstract}

Key words: mulberry leaves, nutritional supplements, biological aspects, Bombyx mori (L.)

\section{Introduction}

Food additions produced from different sources of protein, raise the protein content for the larvae of silkworm which affect the natural silk stored in the silk glands, which in turn leads to the higher production of silk thread and reduces breeder effort for providing larvae with mulberry leaves. Mulberry Mours alba (L.) (Fam: Moraceae) is the sole host plant for feeding the silkworm Bombyx mori Linn, to produce silk. Nutrition plays an important role in improving the growth and development of the silkworm, Bombyx mori (L.), like other organisms. Seki and Oshikane (1959) observed better growth and development of silkworm larvae as well as good quality of cocoons when fed on nutritionally enriched leaves. Enriching mulberry leaves by nutrient supplementation is one of the ways to improve growth rate in B.mori.

The effect of mulberry leaves enriched with amino acids on the growth of $B$. mori has been studied by (Khan and Saha, 1995; Nirwana and Kaliwal, 1998 and Radjabi, 2010). The protein content of the silk gland, fat body, and muscles was found to increase significantly when larval food was supplemented with ascorbic acid (Quraiza et al.2008). Different combinations of mineral nutrients were found to improve larval growth and silk production (Ahmad 1993). Mulberry leaves enriched with nickel chloride and/or potassium iodide has increased cocoons weight at low concentrations (Islam et al. 2004). The growth and development of larvae, and subsequent cocoons production, are greatly influenced by the nutritional quality of mulberry leaves (Masthan et al.2011). The aim of this study is to evaluate the effect of different nutritional substances added to the mulberry leaves on silkworm, Bombyx mori. L.

\section{Material and Methods}

The experiments were conducted in the laboratories of the Department of Plant Protection, Faculty of Agriculture, AL-Azhar Univ., Nasr City, Cairo, Egypt.

\section{Mulberry leaves and silkworm hybrid resources}

Mulberry variety rose was planted in experimental field in the Faculty of Agriculture, ALAzhar Univ, Nasr City, Cairo, Egypt. Eggs of the silkworm hybrid (HoxKKxG2xV2), [Produced by sericulture and agriculture experiment station, Vra Tza, Bulgaria silkworm, B.mori, L.], were obtained from the Sericulture Research Department of Plant Protection Research Institute, Agricultural Research Centre, (ARC.) at Giza- Egypt.

Source of protein.

Four sources of protein supplements were used: (pollen, royal jelly, amino acid (amino meg) and bee honey).

\section{Silkworm rearing technique:}

Preparation for rearing: Before beginning of rearing, the rearing room and appliances were thoroughly cleaned and the floor was washed with $5 \%$ bleaching powder solution. The whole room was disinfected by spraying with $2.5 \%$ sanitech in $0.5 \%$ slacked lime solutions (Dandin et al., 2003).

Incubation of eggs: 
The eggs were procured and incubated by adopting standard incubation and dark treatment practices (Krishnaswami, 1973).

\section{Brushing and rearing:}

The newly hatched larvae of the hybrid (HoxKKxG2xV2), were placed separately, in the disinfected rearing trays supplied with tender mulberry leaves from M.alba var. (Rose) cut into small squares of $0.25 \mathrm{~cm}^{2}$ each and sprinkled over the egg cards. The neonate larvae crawled over the tender leaves and started feeding. Later, cards were tapped onto the other rearing bed, whereas the remaining worms were brushed out. Bed cleaning was done once during the first instar and twice during second one. Two beds each containing 3000 larvae for young instar (from $1^{\text {st }}$ till $3^{\text {rd }}$ instar) reared only on mulberry leaves and from the beginning of $4^{\text {th }}$ instar four treatments with three mixing rates were replicated three times each replicate contains 100 larvae per tray and in addition to the untreated. This experiment was conducted in completely randomized design with three replications.

The treatments are as follows.

T 1 -pollen grains 2, 4 and $6 \%$ of mulberry leaves. T 2 - Royal jelly 2, 4 and $6 \%$ of mulberry leaves. T 3 - Amino acid 2, 4 and $6 \%$ of mulberry leaves. T4 - Bee honey 2, 4 and $6 \%$ of mulberry leaves.

T 5 - Untreated (without additions).

Required quantities of mulberry leaves and pollen, royal jelly, amino acid and bee honey were weighed and supplemented with mulberry leaves for feeding fourth and fifth instar larvae. The larvae were fed on M.alba var. (Rose) mulberry leaves with supplements till pupation. Collapsible frames were used as montages for cocoon spinning After ten days of spinning, cocoons, those were collected.

\section{Silkworm performance:}

Biological aspects:

Larval duration: Total larval duration was calculated from egg hatching till cocoon spinning for each treatment.

Larvae weight: At the end of fourth and fifth larval instars, three replicates were taken, each replicate consisted of twenty larvae and were weighed and the average weight was calculated.

Larval mortality: At the beginning of fourth larval instar, 300 larvae were separated from the mass rearing and used for estimating mortality percentage for the grown larvae. The mortality percentages among the fourth and fifth instars were calculated according to the following formula of Megalla (1984).

Percentage of mortality $=$ No. of dead larvae $/$ Total No. of larvae X 100.

Pupal weight: Pupae of the previous cocoons of each treatment after being sexed, were removed from cocoons and weighed separately, the average weight was calculated.

\section{Economical parameters. \\ Cocoon indices:}

Weight of cocoons: Twenty fresh cocoons were cut and pupae were sexed. The whole cocoons were weighed separately for each sex. Cocoons from each treatment were carefully opened and pupae were sexed, then 30 cocoon of each sex were weighed separately and the average weight for each was calculated.

Fresh of cocoon weight: Twenty fresh cocoons were opened and pupae were sexed. The whole cocoons were weighed separately for each sex.

Cocoons shell weight: After removing the pupae from the previous cocoons as mentioned, and cleaning them from exuviae, those were weighed and the average weight was estimated.

Cocoon shell ratio \%: Cocoon shell ratio was calculated for both sexes in each treatment according to the formula of Krishnaswami et al. (1973) as follows.

Cocoon shell ratio $(\%)=$ Cocoon shell weight $/$ Fresh cocoon weight $\mathrm{X100.}$

Biological and economic parameters data were statistically analyzed (Little \& Hills 1975) using ANOVA implemented by the Costat software program.

\section{Results and discussion.}

Biological parameters of (Bombyx mori, L) hybrid (HoxKKxG2Xv2) fed on mulberry leaves (Rose variety) mixed with different protein sources.

\section{Larval duration.}

Data in (Table 1) show that the larval duration of silkworm larvae fed on mulberry leaves treated by pollen grains recorded 26.16, 25, $66 \& 25.16$ days for the 2,4 and $6 \mathrm{~g}$ of mulberry leaves treatments, respectively. The feeding on untreated mulberry leaves lead to slightly prolongation (28.98days) with no significant differences.

It is clear that silkworm feeding on M.alba var. (Rose variety) treated with pollen recorded the shortest mean of larval duration (25.66 days) followed by royal jelly, amino acid and bee honey treatments (26.37, 26.99, and 27.70 days). Statistical analysis showed that all the protein supplements caused highly significant decrease in larval duration than that of the untreated, while pollen grains effect was superior to royal jelly, amino acid and bee honey as source of protein for silkworm hybrid.

These results are supported by the findings of Krishnan et al. (1995) who they showed that the hydrolyzed soyaprotein (P-soyatase) supplementation decreased the larval duration increased the accumulation of haemolymph protein, larval weight and cocoon characters. 
Larval weight (Fourth and fifth larval instars.)

The data (Table, 1)showed that the highest mean weights of ten larvae (fourth instar larvae) recorded $1.630,1.257,1.071$ and $1.001 \mathrm{~g}$ for the four treatments of pollen grains, royal jelly, amino acid and bee honey, respectively, and when they fed on untreated mulberry leaves those weighed $0.878 \mathrm{~g}$, with significant difference between pollen grains treatment and untreated $(\mathrm{P}=0.008)$.

As shown in the same table, one larva of the fifth instar (at the beginning of stadium) recorded the mean weights of $0.567,0.520,0.476,0.458$ and $0.445 \mathrm{~g}$ for (HoxKKxG2xV2) hybrid larvae fed on mulberry leaves treated by pollen grains, royal jelly, amino acid and bee honey and the untreated, respectively. The fifth larval instar (at the end of stadium) fed on mulberry leaves treated with the pollen grains gave the means of larval weights $(1.860,1.888,1.922 \mathrm{~g})$ for $2,4,6 \%$ in the pollen grains treatment, while they recorded $1.639 \mathrm{~g}$ for the untreated larva (Table 1). It is clear that silkworm feeding on M.alba var. (Rose variety) mixed with $6 \%$ pollen grains recorded the highest means of larval weight followed by royal jelly, amino acid and bee honey.

The presented results are in conformity with those reported by Horie and Watanabe (1983). They showed that the supplementation of soya bean protein increased the protein and amino acid content in the larval haemolymph of the silkworm. Mahmoud (2000) and Ashour (2005) reported that the superiority of Kokuso-27 might be explained by its increased amounts of crude protein, soluble sugar and starch content in their leaves, which might improve the health and growth of larvae, perhaps by increasing the rates of the digestive and oxidizing enzymes which help in utilizing food and increasing food consumption.

Table 1. Effect of feeding mulberry leaves with protein supplements on certain biological parameters in silkworm during spring season, of 2016.

\begin{tabular}{|c|c|c|c|c|c|c|c|}
\hline \multirow{3}{*}{$\begin{array}{l}\text { Protein } \\
\text { Supplements }\end{array}$} & \multirow{3}{*}{$\begin{array}{l}\text { Mixing } \\
\text { rate \% }\end{array}$} & \multicolumn{5}{|c|}{ Larval weights in (g) } & \multirow{3}{*}{$\begin{array}{l}\text { Larval } \\
\text { duration } \\
\text { (days) }\end{array}$} \\
\hline & & \multirow{2}{*}{$\begin{array}{l}\text { Fourth } \\
4^{\text {th }}\end{array}$} & \multirow{2}{*}{$\begin{array}{l}\text { Mortality } \\
\% \\
\end{array}$} & \multicolumn{2}{|l|}{ Fifth $5^{\text {th }}$} & \multirow{2}{*}{$\begin{array}{l}\text { Mortality } \\
\%\end{array}$} & \\
\hline & & & & Immature & Mature & & \\
\hline \multirow{4}{*}{$\begin{array}{l}\text { Pollen } \\
\text { grains }\end{array}$} & $2 \%$ & $1.498^{b}$ & 4 & $0.511 b$ & $1.860 \mathrm{abc}$ & 6 & $26.16 b c$ \\
\hline & $4 \%$ & $1.677^{\mathrm{a}}$ & 3 & $0.584 \mathrm{a}$ & $1.888 \mathrm{ab}$ & 4 & $25.66 b c$ \\
\hline & $6 \%$ & $1.714^{\mathrm{a}}$ & 2 & $0.605 \mathrm{a}$ & $1.922 \mathrm{a}$ & 2 & $25.16 \mathrm{c}$ \\
\hline & Mean & $1.630 \mathbf{a}$ & 3 & $0.567 \mathbf{a}$ & $1.890 \mathbf{a}$ & 4 & $25.66 d$ \\
\hline \multirow{4}{*}{$\begin{array}{l}\text { Royal } \\
\text { jelly }\end{array}$} & $2 \%$ & $1.211^{\mathrm{d}}$ & 9 & $0.467 \mathrm{de}$ & $1.715 \mathrm{de}$ & 9 & $26.96 \mathrm{abc}$ \\
\hline & $4 \%$ & $1.224^{\mathrm{d}}$ & 7 & $0.505 b c$ & $1.807 \mathrm{bcd}$ & 6 & 26.99abc \\
\hline & $6 \%$ & $1.336^{\mathrm{c}}$ & 5 & $0.590 \mathrm{a}$ & $1.900 \mathrm{a}$ & 4 & $25.16 \mathrm{c}$ \\
\hline & Mean & $1.257 \mathbf{b}$ & 7 & $0.520 \mathbf{b}$ & $1.807 \mathbf{a}$ & 6.4 & $26.37 \mathrm{c}$ \\
\hline \multirow{4}{*}{$\begin{array}{l}\text { Amino acid } \\
\text { (amino meg) } \\
\text { trade name }\end{array}$} & $2 \%$ & $1.005^{\mathrm{e}}$ & 11 & $0.454 \mathrm{de}$ & $1.744 \mathrm{de}$ & 10 & $27.66 \mathrm{ab}$ \\
\hline & $4 \%$ & $1.054^{\mathrm{e}}$ & 9 & $0.478 \mathrm{cde}$ & $1.776 \mathrm{cde}$ & 9 & $27.14 \mathrm{abc}$ \\
\hline & $6 \%$ & $1.153^{\mathrm{d}}$ & 8 & $0.496 b c$ & $1.798 \mathrm{bcd}$ & 7 & $26.16 b c$ \\
\hline & Mean & $1.071 \mathrm{c}$ & 9.4 & $0.476 \mathbf{c}$ & $1.773 b$ & 8.7 & $26.99 b c$ \\
\hline \multirow{4}{*}{$\begin{array}{l}\text { Bee } \\
\text { honey }\end{array}$} & $2 \%$ & $0.981^{\mathrm{e}}$ & 13 & $0.450 \mathrm{e}$ & $1.699 \mathrm{e}$ & 14 & $28.69 \mathrm{a}$ \\
\hline & $4 \%$ & $1.007^{\mathrm{e}}$ & 12 & $0.443 \mathrm{e}$ & $1.715 \mathrm{de}$ & 12 & $27.66 \mathrm{ab}$ \\
\hline & $6 \%$ & $1.014^{\mathrm{e}}$ & 9 & $0.481 \mathrm{~cd}$ & $1.701 \mathrm{e}$ & 10 & $26.76 \mathrm{abc}$ \\
\hline & Mean & $1.001 \mathrm{~d}$ & 11.4 & $0.458 \mathbf{d}$ & $1.705 \mathrm{c}$ & 12 & $27.70 \mathbf{b}$ \\
\hline Untreated & Mean & $0.878 \mathbf{e}$ & 14 & $0.445 d$ & $1.639 d$ & 16 & $28.98 \mathbf{b}$ \\
\hline $\mathbf{P}$ & & 0.0567 & & 0.016 & 0.053 & & 1.117 \\
\hline L.S.D.V*H & & 0.0439 & & 0.0127 & 0.041 & & 2.043 \\
\hline
\end{tabular}

\section{Larval mortality.}

The lowest mean mortality percentages $(4,3$ and $2 \%$ ) in the $4^{\text {th }}$ larval instar were obtained when larvae were fed on mulberry leaves mixed with pollen grains. While the highest one (11\% on average) was recorded when larvae fed on bee honey followed by amino acid and royal jelly (9.4 and 7\% in average). The fifth instar larvae gave the same trend of mortality, it is clear that feeding on leaves mixed with pollen grains is suitable for silkworm. These results are supported by the finding of Zannoon (1999) who reported that rearing B. mori larvae with Kokuso-27 led to shorter larval durations and lower larval mortality rate relative to feeding on it than the native variety. 
Economical parameters:

Cocoon indices.

Fresh cocoon weight (F.C.W).

Feeding on M.alba (Rose) mulberry leaves mixed with pollen, royal jelly, amino acid and bee honey supplements resulted in insignificant increase in fresh cocoon weight. The fresh cocoon mean weights were $(0.791,0.735,0.745,0.712 \mathrm{~g})$ for female and $(0.718,0.696,0.680,0.668 \mathrm{~g})$ for male 2,4 and $6 \%$ protein supplements in the four treatments, respectively, compared to 0.687 and $0.667 \mathrm{~g}$ for the three mixing percentages uintreated for female and male Highly significant differences were recorded in all treatments comparing with untreated.

\section{Cocoon shell weight (C.S.W).}

Cocoon shell weights marked variation between male and female and also between different treatments. Results of cocoon shell weights followed the same trend of the fresh cocoon weights previously pointed out. Supplementation with pollen led to the heaviest cocoon shell of females and males of hybrid.
The means of cocoon shell weights were $(0.159$, $0.149,0.140,0.130 \mathrm{~g})$ for female and $(0.129,0.117$, $0.117,0.114 \mathrm{~g}$ ) for male for the three mixing rates 2 , 4 and $6 \%$ protein supplements in the four treatments, respectively, in comprising 0.131 and $0.111 \mathrm{~g}$ of female and male (untreated). With highly significant differences among all treatments (Table 2).

\section{Cocoon shell ratio (C.S.R):}

Feeding on M.alba var. (rose) mulberry leaves mixed with pollen, royal jelly, bee honey and amino acid supplements (Table 2) resulted in insignificant increase in cocoon shell ratio. The cocoon shell ratio were $19.77,18.66,17.69,17.70 \mathrm{~g}$ ) for female and $(17.97,16.83,17.28,17.09 \mathrm{~g})$ for male of three mixing rates 2,4 and $6 \%$ protein supplements in four treatments, respectively, in comparison to 17.80 and $16.80 \%$ for female and male in untreated. With significant differences were found in the first three treatments for female and male compared to untreated. It is clear that feeding on pollen was suitable for silkworm Bombyx mori, (L) rearing.

Table 2. Effect of feeding mulberry silkworm on mulberry leaves mixed with protein supplements (pollen grains, royal jelly, bee honey and amino acid) on certain economical parameters of (Female and Male).

\begin{tabular}{|c|c|c|c|c|c|c|c|c|c|}
\hline \multirow{3}{*}{$\begin{array}{l}\text { Protein } \\
\text { Supplements }\end{array}$} & \multirow{3}{*}{$\begin{array}{l}\text { Mixing } \\
\text { rate } \%\end{array}$} & \multicolumn{8}{|c|}{ Male and female cocoon parameters } \\
\hline & & \multicolumn{2}{|c|}{$\begin{array}{l}\text { Mean of fresh } \\
\text { cocoon weight }(g) .\end{array}$} & \multicolumn{2}{|c|}{$\begin{array}{l}\text { Mean of cocoon } \\
\text { shell weight }(\mathrm{g}) \text {. }\end{array}$} & \multicolumn{2}{|c|}{$\begin{array}{l}\text { Mean of pupae } \\
\text { weights }(g) \text {. }\end{array}$} & \multicolumn{2}{|c|}{$\begin{array}{l}\text { Mean of cocoon } \\
\text { shell ratio } \\
\text { (C.S.R\%) }\end{array}$} \\
\hline & & Female & male & Female & male & Female & male & Female & male \\
\hline \multirow{4}{*}{$\begin{array}{l}\text { Pollen } \\
\text { grains }\end{array}$} & $2 \%$ & $0.757 \mathrm{abc}$ & $0.698 \mathrm{a}$ & $0.156 a b$ & $0.128 \mathrm{a}$ & $0.618 \mathrm{ab}$ & $0.579 \mathrm{a}$ & $20.54 \mathrm{a}$ & $17.79 \mathrm{ab}$ \\
\hline & $4 \%$ & $0.780 \mathrm{abc}$ & $0.725 \mathrm{a}$ & $0.159 \mathrm{a}$ & $0.129 \mathrm{a}$ & $0.605 \mathrm{ab}$ & $0.585 \mathrm{a}$ & $19.66 \mathrm{ab}$ & $18.34 \mathrm{a}$ \\
\hline & $6 \%$ & $0.838 \mathrm{a}$ & $0.731 \mathrm{a}$ & $0.164 \mathrm{a}$ & $0.131 \mathrm{a}$ & $0.673 \mathrm{a}$ & $0.567 \mathrm{a}$ & $19.11 \mathrm{bc}$ & $17.92 \mathrm{ab}$ \\
\hline & Mean & $0.791 \mathbf{a}$ & $0.718 \mathbf{a}$ & $0.159 \mathbf{a}$ & $0.129 \mathbf{a}$ & $0.632 \mathbf{a}$ & $0.577 \mathbf{a}$ & $19.77 \mathbf{a}$ & $17.97 \mathbf{a}$ \\
\hline \multirow{4}{*}{ Royal } & $2 \%$ & $0.662 \mathrm{~d}$ & $0.681 \mathrm{a}$ & $0.135 \mathrm{abc}$ & $0.111 \mathrm{a}$ & $0.615 \mathrm{ab}$ & $0.627 \mathrm{a}$ & $19.39 \mathrm{ab}$ & $17.38 \mathrm{bc}$ \\
\hline & $4 \%$ & $0.713 b c$ & $0.702 \mathrm{a}$ & $0.151 \mathrm{ab}$ & $0.119 \mathrm{a}$ & $0.636 a b$ & $0.586 \mathrm{a}$ & $18.60 \mathrm{bcd}$ & $16.90 \mathrm{~cd}$ \\
\hline & $6 \%$ & $0.830 \mathrm{ab}$ & $0.704 \mathrm{a}$ & $0.162 \mathrm{a}$ & $0.122 \mathrm{a}$ & $0.665 a b$ & $0.568 \mathrm{a}$ & $18.00 \mathrm{~cd}$ & $16.30 \mathrm{~d}$ \\
\hline & Mean & $0.735 \mathbf{a b}$ & $0.696 \mathbf{a}$ & $0.149 \mathbf{a b}$ & $0.117 \mathbf{a b}$ & $0.639 \mathbf{a}$ & $0.594 \mathbf{a}$ & $18.66 \mathrm{~b}$ & $16.83 \mathrm{~cd}$ \\
\hline \multirow{4}{*}{$\begin{array}{l}\text { Amino acid } \\
\text { (amino meg) } \\
\text { trade name }\end{array}$} & $2 \%$ & $0.697 \mathrm{~cd}$ & $0.660 \mathrm{a}$ & $0.132 \mathrm{bc}$ & $0.112 \mathrm{a}$ & $0.559 \mathrm{~b}$ & $0.536 \mathrm{a}$ & $17.89 \mathrm{~cd}$ & $17.69 \mathrm{a}$ \\
\hline & $4 \%$ & $0.748 \mathrm{bc}$ & $0.687 \mathrm{a}$ & $0.140 \mathrm{abc}$ & $0.120 \mathrm{a}$ & $0.589 \mathrm{~b}$ & $0.551 \mathrm{a}$ & $17.71 \mathrm{~cd}$ & $17.47 \mathrm{bc}$ \\
\hline & $6 \%$ & $0.791 b c$ & $0.694 \mathrm{a}$ & $0.149 \mathrm{abc}$ & $0.121 \mathrm{a}$ & $0.624 b$ & $0.553 \mathrm{a}$ & $17.49 \mathrm{~d}$ & $16.97 \mathrm{~cd}$ \\
\hline & Mean & $0.745 \mathbf{a b}$ & $0.680 \mathbf{a}$ & $0.140 \mathrm{bc}$ & $0.117 \mathbf{a b}$ & $0.590 \mathbf{a}$ & $0.547 \mathbf{a}$ & $17.69 \mathrm{c}$ & $17.28 \mathbf{b}$ \\
\hline \multirow{4}{*}{$\begin{array}{l}\text { Bee } \\
\text { honey }\end{array}$} & $2 \%$ & $0.667 \mathrm{~d}$ & $0.654 \mathrm{a}$ & $0.122 \mathrm{c}$ & $0.113 \mathrm{a}$ & $0.570 \mathrm{~b}$ & $0.522 \mathrm{a}$ & $17.55 \mathrm{~d}$ & $17.13 \mathrm{~cd}$ \\
\hline & $4 \%$ & $0.703 \mathrm{~cd}$ & $0.666 \mathrm{a}$ & $0.130 \mathrm{bc}$ & $0.111 \mathrm{a}$ & $0.593 b$ & $0.535 \mathrm{a}$ & $17.83 \mathrm{~cd}$ & $16.97 \mathrm{~cd}$ \\
\hline & $6 \%$ & $0.767 \mathrm{abc}$ & $0.683 \mathrm{a}$ & $0.140 \mathrm{abc}$ & $0.117 \mathrm{a}$ & $0.624 b$ & $0.563 \mathrm{a}$ & $17.73 \mathrm{~d}$ & $16.97 \mathrm{~cd}$ \\
\hline & Mean & $0.712 b$ & $0.668 \mathbf{a}$ & $0.130 \mathrm{cb}$ & $0.114 \mathbf{b}$ & $0.596 \mathbf{a}$ & $0.540 \mathbf{a}$ & $17.70 \mathbf{c}$ & $17.09 b$ \\
\hline untreated & & $0.687 \mathbf{b}$ & $0.667 \mathbf{a}$ & $0.131 \mathrm{~d}$ & $0.111 \mathbf{b}$ & $0.589 \mathrm{a}$ & $0.549 \mathbf{a}$ & $17.80 \mathrm{c}$ & $16.80 \mathrm{~b}$ \\
\hline \multirow{2}{*}{ L.S.D.V*H } & Treatments & 0.068 & 0.017 & 0.015 & 0.012 & 0.064 & 0.064 & 0.767 & 0.573 \\
\hline & $\begin{array}{l}\text { Mixing rate } \\
\%\end{array}$ & 0.053 & 0.052 & 0.012 & 0.010 & 0.049 & 0.0469 & 0.594 & 0.444 \\
\hline
\end{tabular}


Pupal weights (g).

It was observed higher mean weight of the pupae in case of feeding on royal jelly $0.639 \mathrm{~g}$ for female followed by pollen grains $0.632 \mathrm{~g}$. While the lowest mean weight of pupae was in the case of amino acid $0.590 \mathrm{~g}$ compared to the untreated $0.605 \mathrm{~g}$ (Table 2). The higher mean weight of the male pupae was in the case of feeding royal jelly $0.594 \mathrm{~g}$; followed by pollen grins $(0.577 \mathrm{~g}$.$) , while the lowest mean weight of$ pupae was in the case of bee honey $0.540 \mathrm{~g}$ compared to the untreated male $0.549 \mathrm{~g}$, and female $(0.589 \mathrm{~g})$ (Table 2).

From these results it can be concluded that the nutritional supplements added to mulberry for feeding silkworm larvae were effective in increasing the growth rate and development of silkworm larva. The treatment of silkworm larvae with nutrient supplement is good in improving the qualities of silk fibre which can be used for yield enhancement in sericulture industry. The presented results agree with (Nguku et al, 2007) cleared that Royal jelly obtained from Apis mellifera colonies increases moulting and larval weight of silkworm B.mori (L). It contains acetylcholine, which is important requirement in the diet of silkworm larvae for normal moulting as well as growth. The rapid growth and developmentl as well as increasing number of eggs can be obtained by addition royal jelly to the normal mulberry leaves. Effect of mulberry leaves fortified with royal jelly does not show any significant differences on shell weights over normal feeding of silkworm. Radjabi, (2010) stated that the actual silk fibre fibroin is derived from four amino acids viz., Alanine, Serine, Glycine and Tyrosin, which come from the food material of silkworm. The author showed that amino acid Alanine plays an important role in metabolism of glucose, tryptophan and organic acid. Aspergin used as aspartic acid by silkworm is one of the essential amino acids, deficiency of which results growth retardation. The same author added that supplementation of amino acids solutions, dissolved in distilled water by spread in fresh mulberry leaves after being diluted in different concentrations with feeding material at definite level is effective for improvement of growth and development of silkworm, but a high level beyond a certain level does not have a positive effect.

\section{References:}

Ahmad, Z. (1993) Effect of nitrogen, phosphorous and potassium treated mulberry leaves on larval development and silk yield of Bombyx mori L. M.Sc. Thesis, Department of Agricultural Entomology, University of Agriculture, Faisalabad. Ashour A. (2005) Silkworm feeding trials for evaluating the varietal effect of three mulberry leaves on the silkworm growth and cocoon yield quality. Egyptian Journal of Agricultural Research 83(3): 1043-1049.
Dandin, S. B., Jayant Jayaswal and Giridhar, K. (2003) Handbook of sericulture technologies, Central Silk Board, Bangalore, $287 \mathrm{pp}$.

Horie, and K. Watanabe. (1983) Design of the composition of the artificial diet for the silkworm bombyx mori by linear programming method: application of ingredients of food for domesticated animals and fowls, Bull. Seric. Expt. Stn., 26. 259-283.

Islam, M. d. R, Ali, M. d. AO, Paul DK, Sultana S, Banu NK, Islam Md R. (2004): Effect of Salt, Nickel chloride supplementation on the growth of silkworm, Bombyx mori L. (Lepidoptera: Bombycidae). Journal of Biological Sciences 4(2): 170-172.

Khan, M. D, Saha, B. N. (1995): Growth and development of the mulberry silkworm, Bombyx mori L. on feed supplemented with alanine and glutamine. Sericolgia 35: 657-663.

Krishnaswami, M. N.; Narasimhanna, S. K.;Suryanarayana and S. Kumararaj (1973): Manual on sericulture-2, Silkworm Rearing, FAO, Rome, 42-43.

Krishnan, K. M. Subburathinam and S. Janarthan.(1995) Effect of hydrolyzed protein (P Soyatose) on haemolymph protein profile, larval and pupal characters of the silkworm, Bombyx mori L. (lepidoptera: Bombycidae), Sericologia, 35: 227-235.

Little, T. M \& Hills, F. J. (1975) Textbook of statistical methods in agricultural research. University of California at Davis, California, USA.

Masthan K, Kumar TR, Narsimha Murthy CV. (2011): Beneficial affects of blue green algae Spirulina and yeast Saccharomyces cerevisiae on cocoon quantitative parameters of silkworm B.mori L. Asian Journal of Microbiology Biotechnology, 13(1): 205-208.

Mahmoud, S. (2000): Feeding effect of different mulberry varieties on Bombyx mori L. silkworm. Egypt Journal Appl. Sci., 15 (6): 253 -261.

Megalla, A. E. (1984): Effect of certain dietary constituents on silkworms.Ph. D. Thesis, Faculty of Agric. Ain Shams Unive, Egypt.

Nguku E. K., Muli E. M. and Raina S. K. (2007): Larvae, Cocoon and Post-cocoon characteristics of Bombyx mori L. (Lepidoptera: Bombycidae) fed on mulberry leaves fortified with Kenyan Royal Jelly. J. Appl. Sci. Environ. Vol. 11(4) 85 -89 .

Nirwana, R. B, Kaliwal, B. B. (1998): Effect of thiamine on commercial traits and biochemical contents of the fat body and haemolymph in the silkworm Bombyx mori L. Sericolgia 38: 639646.

Quraiza, M. T. F, Rathi CR, Muthu PT, Das SM, Bai MR. (2008): A study on the effect of ascorbic acid in modifying Tissue protein content 
and economic traits of Bombyx mori L. Journal of Basic and Applied Biology 2(3- 4): 32-35.

Seki, K, and Oshikane K. Res. (1959): Reports. Fac. Textile and Sericulture, Shinshu University.

Radjabi, R. (2010): Effect of mulberry leaves enrichment with amino acid supplementary nutrients on silkworm, Bombyx mori. at North of Iran. Academic Journal of Entomology, 3 (1): 45-
Zannoon, A. A. (1999): Effect of alternative feeding on mulberry leaves of different varieties on the silkworm, Bombyx mori L. Journal of Productivity \& Development (Agric. Research) (Institute of Efficient Productivity, Zag. Univ, Egypt). 4(2): 1-7.

$$
\begin{aligned}
& \text { تأثير الإضافات الغذائية المختلفة لأولق التوت على النواحى الحياتية والإقتصادية لدودة الحرير التوتية. }
\end{aligned}
$$

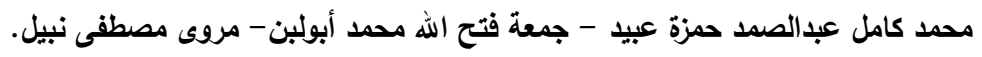

$$
\begin{aligned}
& \text {-1قسم وقاية النبات -كلية الزراعة -جامعة الأزهر الشريف - مدينة نصر - القاهرة. } \\
& \text {-2معهل بحوث وقاية النباتات -مركز البحوث الزراعية - الجيزة -مصر. }
\end{aligned}
$$

تم إنجاز هذا العمل بمعامل كلية الزراعه جامعة الأزهر الثريف بالقاهرة -مدينة نصر .حيث نم تغذية يرقات ديدان الحربر التوتية

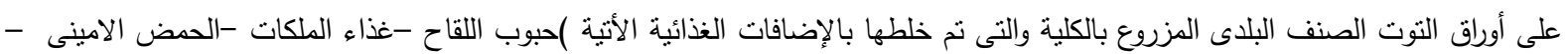

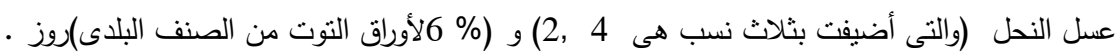

وتم إختبار هجين مستورد من بلغاريا (HoxKKxG2xV2)بواسطة قسم بحوث الحربر التابع لمركز البحوث الزراعية بالجيرة .ونم تقسيم اليرقات

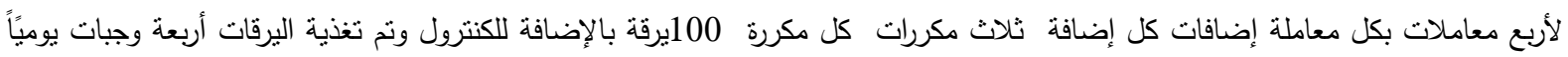
بدايةً من العمر اليرقى الأول حتى دخول اليرقات التعشيش وتكوين الثرنقة.

وأظهرت النتائج تفوق المعاملة المضاف اليها حبوب اللقاح عن المعاملات الأخرى مقارنة بالكنترول يليها غذاء الملكات والحمض الأمينى وكان عسل النحل فى المسرتبة الأخيرة.

وكانت الأفضلية لحبوب اللقاح بين المعاملات من حيث التحسين فى الصفات البيولوجية والإقتصادية محل الدراسة فى زيادة منوسطات الأوزان

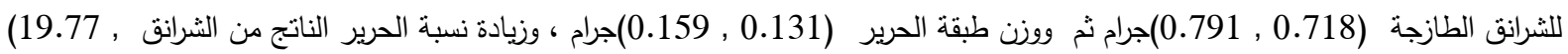
(17.79جرام للانثى والذكر على التوالى .كذلك النقص فى مدة الطور البرقى ونسبة الوفيات مقارنة بالإضافات الأخرى والكنترول. 